Вестник ВГУ. Серия: Право

УДК 347.73

DOI https://doi.org/10.17308/vsu.proc.law.2020.3/2986

\title{
ДЕНЬГИ КАК МЕРА СТОИМОСТИ \\ В ИМУЩЕСТВЕННЫХ НАЛОГОВЫХ ПРАВООТНОШЕНИЯХ
}

\author{
А. В. Красюков \\ Воронежский государственный университет \\ Поступила в редакцию 24 апреля 2020 г.
}

\begin{abstract}
Аннотация: статья посвящена изучению признаков илущественных отношений, являюшихся предлетол налогового права. Анализируется стоимостной характер илущественных налоговых правоотношений. В статье также подробно изучается властная характеристика данных правоотношений. На основе проведенного исследования делается вывод, что властный характер илущественньх налоговых правоотношений не препятствует реализации в них эконолического закона стоилости.

Ключевые слова: деньги, стоилость, илущественное отношение, предмет налогового права.
\end{abstract}

\begin{abstract}
: the article is devoted to the study of signs of property relations, the subject of tax law. The author analyzes the value character of property tax relations. The article also examines in detail the power characteristics of these relationships. Based on the study, the author comes to the conclusion that the imperious nature of property tax relations does not impede the implementation of the economic law of value in them.
\end{abstract}

Key words: money, value, property relationship, subject of tax law.

В науке финансового права налоговые отношения традиционно принято характеризовать как властно-имущественные, в которых отношения власти неотделимы от имущественных отношений. Поэтому налоговые отношения не строятся как исключительно властные правоотношения, ни тем более как исключительно имущественные отношения ${ }^{1}$. Некоторым авторам представляется ошибочным определять характер налоговых отношений как властный. Они выдвигают иные формы взаимодействия государства и налогоплательщика в рамках налоговых отношений. Поскольку отношения власти в налоговом праве направлены на взаимодействие публичного и частного интересов, т. е. представляют способ организации интересов, то наиболее правильно характеризовать налоговые отношения как организационно-имущественные ${ }^{2}$.

Думается, что в данной ситуации делается попытка противопоставить характер воздействия государства на имущественные налоговые отношения, который является властным по своей природе, поскольку преодолеть

${ }^{1}$ См.: Ровинский E. A. Основные вопросы теории советского финансового права. М., 2017. С. 137.

${ }^{2}$ См.: Шаукенов А. T. Некоторые проблемы теории и фрилософии налогового права. Алматы, 2009. С. 111-113.

(C) Красюков А. В., 2020 


\section{Финансовое право. Налоговое право}

естественное нежелание собственника расстаться со своим имуществом можно только с помощью принуждения (реального или потенциального), и результат этого воздействия заключается в организации, упорядочении данных отношений.

Конституционный Суд РФ в своих многочисленных правовых позициях по налоговым спорам также исходит из этого постулата. Имущественными данные отношения являются в силу того, что направлены на удовлетворение имущественных притязаний государства ${ }^{3}$.

Властный характер налоговых отношений проявляется в субординации сторон, в силу которой:

- налогоплательщику вменяется обязанность повиновения, в том числе в форме своевременной и полной уплаты налога;

- налоговому органу, действующему от имени государства, принадлежит властное полномочие - обеспечить исполнение налогоплательщиком своих обязанностей ${ }^{4}$.

При этом Конституция РФ устанавливает пределы такого властноимущественного притязания государства. Налоговые имущественные отношения не должны, во-первых, приобретать характер санкций, а, во-вторых, отменять или умалять права и свободы человека и гражданина ${ }^{5}$.

По сути, Конституционный Суд РФ сформулировал модель налоговых отношений по взиманию налогов, согласно которой государство является управомоченным субъектом (кредитором), а налогоплательщик - обязанным (должником). Субординация в рамках налоговых отношений, проявляющаяся в распределении прав и обязанностей сторон, не свидетельствует о властном характере данных отношений. В любом обязательстве кредитор имеет больше прав, а должник - больше обязанностей, что проявляется в возможности кредитора требовать определенного поведения от должника. Безусловно, это можно считать властью, но не в публично-правовом смысле

${ }^{3}$ Об отказе в принятии к рассмотрению жалобы открытого акционерного общества «Ростелеком» на нарушение конституционных прав и свобод положениями пунктов 5 и 7 статьи 78 Налогового кодекса Российской Федерации и части 4 статьи 200 Арбитражного процессуального кодекса Российской Федерации : определение Конституционного Суда РФ от 8 февраля 2007 г. № 381-О-П // Вестник Конституционного Суда РФ. 2007. № 5.

${ }^{4}$ По делу о проверке конституционности пунктов 2 и 3 части первой статьи 11 Закона Российской Федерации от 24 июня 1993 года «О федеральных органах налоговой полиции» : постановление Конституционного Суда РФ от 17 декабря 1996 г. № 20-П // Собр. законодательства Рос. Федерации. 1997. № 1. Ст. 197 ; По делу о проверке конституционности положений статьи 113 Налогового кодекса Российской Федерации в связи с жалобой гражданки Г. А. Поляковой и запросом Федерального арбитражного суда Московского округа : постановление Конституционного Суда РФ от 14 июля 2005 г. № 9-П // Там же. 2005. № 30 (ч. 2). Ст. 3200.

${ }^{5}$ По делу о проверке конституционности пунктов 2 и 3 части первой статьи 11 Закона Российской Федерации от 24 июня 1993 года «О федеральных органах налоговой полиции» : постановление Конституционного Суда РФ от 17 декабря 1996 г. № 20-П.

${ }^{6} \mathrm{~B}$ доктрине финансового права есть и другая точка зрения, согласно которой императивность реализуемой в налоговом обязательстве нормы права придает 


\section{Вестник ВГУ. Серия: Право}

Властный характер налоговых отношений, прежде всего, проявляется при установлении налогов, когда государство определяет, какую часть своего имущества налогоплательщик должен передать на публичные нужды. Именно на ограничение суверенного права устанавливать налог направлены нормы Конституции РФ, из которых исходил Конституционный Суд РФ при формулировании вышеуказанной правовой позиции. Вряд ли в процессе взимания налога при соблюдении всех установленных норм его можно превратить в санкцию ${ }^{7}$ или отменить какое-либо право и свободу. Напротив, при установлении налога довольно легко нарушить тонкую грань, отделяющую налог от конфискации, ограничение права собственности от его умаления.

В процессе исполнения налогового обязательства властный характер данных отношений проявляется только в случае неисполнения должником своих обязанностей. Обычно для принудительного исполнения обязательства, применения мер ответственности требуется решение юрисдикционного органа, не являющегося стороной спорного правоотношения. Иными словами, власть принимать решение по существу спора, возникшего при исполнении обязательства, никогда не принадлежит стороне этого обязательства, даже если этой стороной является государство.

В налоговом обязательстве его принудительное исполнение имеет оперативный характер ${ }^{8}$, что обусловлено интересами исполнения бюджета. При конфрликте интересов бюджета и интересов частного субъекта выбор делается в пользу первоочередного удовлетворения публичного интереса, но с обязательным предоставлением возможности последующей защиты интереса частного. В этом и проявляется властный характер имущественных правоотношений, опосредованных налоговым обязательством.

Кроме того, властный характер имущественных налоговых правоотношений проявляется в законодательном установлении жестких границ ๓ допустимого поведения как налогового должника, так и налогового кре을 дитора. Это обусловлено публично-правовым характером данных отношений.

Тем самым независимо от отраслевой принадлежности имущественных отношений главнейшим признаком, отличающим их от построенных на тех же началах правового регулирования неимущественных отноше-

212 ний, является то, что они возникают по поводу имущества, материальных и иных экономических благ. альных благ ставит под сомнение возможность однородного регулирова-

особый характер правам кредитора, которые приобретают характер властного веления для должника (см.: Карасева М. В. Финансовое правоотношение. Воронеж, 1997. С. 283-284).

${ }^{7}$ Вероятно, КС РФ здесь имел в виду конфискацию.

${ }^{8}$ Кроме случаев, прямо предусмотренных законом, имеющих либо очевидно спорный характер, либо способных нарушить права и свободы физических лиц, не являющихся предпринимателями, или иммунитет бюджета.

${ }^{9}$ См.: Егоров Н. Д. Гражданско-правовое регулирование общественных отношений. Л., 1988. С. 7. 


\section{Финансовое право. Налоговое право}

ния этих отношений со стороны права. Действительно, одни имущественные отношения имеют товарно-денежный характер и направлены на непосредственное удовлетворение потребностей сторон данных правоотношений, другие - имеют безэквивалентный характер, не являясь средством прямой реализации имущественного интереса сторон, опосредуя отношения распределительного характера.

Принято считать, что гражданские имущественные отношения складываются по поводу материальных благ, имеющих, как правило, форму товара, и, тем самым, являются по своей природе товарно-денежными. А налоговые имущественные отношения направлены на материальные блага, выраженные в денежных средствах и не предназначенные для эквивалентного обращения (не имеющие стоимостного характера) ${ }^{10}$. Данные отношения являются по своей экономической природе финансовыми ${ }^{11}$.

В товарно-денежных отношениях в качестве такого объекта выступает товар, т. е. продукт, предназначенный для обмена ${ }^{12}$, а в финансовых отношениях таковыми являются финансовые ресурсы - материальные блага, предназначенные для безэквивалентного движения в ходе образования и использования денежных фондов ${ }^{13}$. В частности, налоговые отношения возникают по поводу таких разновидностей финансовых ресурсов, как налог, сбор, недоимка, пени, штрафр.

Различная экономическая природа данных отношений проявляется еще и в том, что они возникают на различных стадиях: налоговые имущественные отношения возникают на стадии распределения и перераспределения общественного продукта, а товарно-денежные отношения - на стадии обмена и потребления ${ }^{14}$.

Однако целостность воспроизводственного процесса, на разных стадиях которого складываются данные отношения, в итоге предопределяет сущностную идентичность имущественных отношений, регулируемых гражданским и налоговым правом. Данные отношения предлагается определить как имущественные отношения процесса расширенного воспроизводства ${ }^{15}$.

Не следует забывать, что имущественные отношения, регулируемые налоговым правом, практически всегда являются денежными, т. е. возникают по поводу денег. В экономической теории и юридической науке традиционно считается, что деньги в финансовых отношениях, в отличие от

${ }^{10}$ См.: Карасева М. В. Налоговое правоотношение : имущественная идентичность и проблема адаптации частноправовых конструкций // Закон. 2010. № 11. C. 58-59.

${ }^{11}$ См.: Ровинский E. А. Указ. соч. С. 134.

${ }^{12}$ См.: Гражданское право : учебник / под ред. Ю. К. Толстого, А. К. Сергеева. СПб., 1996. С. 415-416.

${ }^{13}$ См.: Финансы : учебник / под ред. В. М. Родионовой. М., 1993. С. 10.

${ }^{14}$ См.: Карасева (Сенцова) М. В. Гражданско-правовая детерминация налогового права : понятие и сущностная обусловленность // Вестник Воронеж. гос. ун-та. Серия: Право. 2013. № 2. С. 321.

${ }^{15}$ См.: Там же. С. 321-322. 


\section{Вестник ВГУ. Серия: Право}

гражданского оборота, не являются ни средством обращения, ни мерилом стоимости ${ }^{16}$. Являясь объектом налоговых отношений, они, прежде всего, выступают средством платежа ${ }^{17}$.

Представляется, что полностью исключать роль денег как меры стоимости в налоговых отношениях нельзя. С развитием финансовой науки существенно изменился взгляд на стоимостные отношения. В настоящее время к числу стоимостных отношений относятся и финансовые отношения, поскольку они опосредуют движение созданной в общественном производстве стоимости в рамках распределительных отношений ${ }^{18}$.

В подтверждение данного подхода можно привести довод о том, что самой распространенной налоговой базой в современном законодательстве является стоимостная характеристика объекта налогообложения. Тем самым законодателя интересует созданная налогоплательщиком стоимость, чтобы часть ее перераспределить в пользу государства. Налоги, которые используют для определения налоговой базы, имеют иные характеристики объекта налогообложения (количество, мощность и т. п.), по своей сути являются косвенным налогообложением дохода налогоплательщика, т. е. полученной им в процессе общественного производства стоимости. Например, чем больше у налогоплательщика доход, тем дороже и мощнее его автомобили, тем больше его недвижимость.

Об отсутствии непреодолимых препятствий между прямым и косвенным налогообложением дохода (стоимости) свидетельствует, например, возможность применять к вычету при исчислении налога на прибыль организаций или налога на доходы физических лиц (механизмы прямого налогообложения дохода) расходы на уплату торгового сбора (механизм косвенного налогообложения дохода). Это свидетельствует о том, что все налоги, налоговая система в целом направлены на перераспределение созданной налогоплательщиками стоимости, а сами налоговые отношения м в этом смысле являются стоимостными по своему характеру.

을 Другим примером проявления стоимости в налоговых правоотношениях являются пени, которые в соответствии с правовой позицией Конституционного Суда РФ являются компенсацией потерь государственной казны в случае недополучения налоговых платежей в установленный законом срок или незаконного возмещения налога из бюджета ${ }^{19}$. Пени обе-

214 спечивают компенсацию несвоевременности уплаты налога, фактически

${ }^{16}$ См.: Братусь С. Н. Предмет и система советского гражданского права. М., 1963. C. 122 .

${ }^{17}$ См.: Карасева М. В. Деньги - объект имущественных финансовых правоотношений // Законодательство и экономика. 2006. № 11.

${ }^{18}$ См.: Карасева (Сенцова) М. В. Гражданско-правовая детерминация налогового правотворчества и правоприменения // Финансовое право. 2012. № 4.

19 По делу о проверке конституционности пунктов 2 и 3 части первой статьи 11 Закона Российской Федерации от 24 июня 1993 года «О федеральных органах налоговой полиции» : постановление Конституционного Суда РФ от 17 декабря 1996 г. № 20-П ; Об отказе в принятии к рассмотрению жалобы общества с ограниченной ответственностью «Чебаркульская птица» на нарушение конституционных прав и свобод абзацем четвертым пункта 8 статьи 101 Налогового кодекса 


\section{Финансовое право. Налоговое право}

представляя собой размер платы за пользование денежными средствами, поскольку размер пени привязан к ставке рефинансирования ЦБ РФ как некой усредненной стоимости использования денежных средств в экономике государства ${ }^{20}$. Эту же точку зрения разделяют и другие ученые ${ }^{21}$. При этом компенсация, если она уплачивается в дополнение к возврату долга, рассматривается как вознаграждение ${ }^{22}$. Эту гипотезу подтверждает и то обстоятельство, что размер пеней зависит от продолжительности использования денежных средств. Следовательно, пени в налоговых отношениях можно рассматривать как вознаграждение казны за пользование ее фринансовыми ресурсами, иными словами, как стоимость такого пользования ${ }^{23}$.

Следует отметить, что закрепление нормативных положений о пенях в главе НК РФ, посвященной обеспечительным мерам, никоим образом не противоречит вышеуказанной гипотезе. Это обусловлено тем, что само по себе существование обязанности уплатить пени за несвоевременное предоставление денежных средств государству (а не ее уплата или взыскание) может рассматриваться в качестве обеспечительной меры, способствующей добровольной и своевременной уплате налога обязанным лицом.

Другой формой применения денег как меры стоимости в налоговых отношениях являются проценты, уплачиваемые налогоплательщиком при изменении срока уплаты налога. Как и в вышеуказанном случае, проценты являются формой платы государству за пользование его финансовыми ресурсами. В отличие от пени проценты, уплачиваемые за предоставление отсрочки (рассрочки) и инвестиционного налогового кредита, представляют собой договорную форму вознаграждения, а не деликтную. Напротив, проценты, уплачиваемые государством налогоплательщику за излишнее взыскание или несвоевременный возврат излишне уплаченных налогов, являются стоимостью пользования денежными средствами налогоплательщика.

Кроме того, само налоговое администрирование имеет определенную стоимость, складывающуюся из затрат государства на его осуществление.

Российской Федерации : определение Конституционного Суда РФ от 10 марта 2016 г. № 571-О // Вестник Конституционного Суда РФ. 2016. № 6.

${ }^{20}$ См.: Разгильдиева М. Б. Проблемы теории налогово-правовой ответственно- 215 сти // Очерки налогово-правовой науки современности / под общ. ред. Е. Ю. Грачевой, Н. П. Кучерявенко. М. ; Харьков, 2013. С. 542 ; Разгильдиева М. Б. К вопросу о функциях налогово-правовой ответственности // Налоги. 2014. № 1. С. 38-42.

${ }^{21}$ См., например: Цинделиани И. А. Правовое регулирование взыскания недоимок по налогам, сборам, пеням, штрафам с налогоплательщиков - физических лиц : современные законодательство и правоприменительная практика // Финансовое право. 2012. № 11. С. 14-21.

${ }^{22}$ См.: Райзберг Б. А., Лозовский Л. Ш., Стародубиева Е. Б. Современный экономический словарь. 6-е изд., перераб. и доп. М., 2011.

${ }_{23}^{23}$ Данный подход не работает лишь в случае уплаты пеней налоговым агентом при неудержании налога у налогоплательщика. В данном случае пени являются скорее штрафной неустойкой. 


\section{Вестник ВГУ. Серия: Право}

Данная стоимость способна оказывать прямое воздействие на возникновение и прекращение имущественных налоговых правоотношений. В силу принципа экономической эффрективности налогообложения государство устанавливает только те налоги, которые покрывают расходы на их администрирование. Если налог не будет покрывать затраты на его администрирование, то государство в конечном итоге всегда его отменяет или изменяет, если только социальный эффект от его неизменного характера не является более важным ${ }^{24}$.

Таким образом, на распределение финансовых ресурсов влияет стоимость, складывающаяся не только в гражданском обороте, но и в процессе финансовой деятельности. Если гражданско-правовая цена влияет на пропорцию распределения финансовых ресурсов ${ }^{25}$ (например, стоимость банковского кредита влияет на размер компенсации, выплачиваемой налогоплательщиком государству или наоборот), то стоимость налогового администрирования влияет на саму возможность такого распределения, исключая те налоговые платежи, стоимость взимания которых слишком велика.

Тем самым, если цена является денежным выражением стоимости товара, то стоимость налогового администрирования определяется балансом доходов от взимания налога и расходов на его администрирование.

Проведенное исследование со всей очевидностью демонстрирует, что властный характер имущественных налоговых правоотношений не является препятствием для реализации в них экономического закона стоимости. При этом стоимостной характер имущественных налоговых правоотношений имеет существенные особенности, обусловленные характером этих отношений.

${ }^{24}$ В качестве примера влияния стоимости налогового администрирования на налоговые отношения можно привести изменения в ст. 48 НК РФ: сначала была установлена минимальная сумма налогового долга, за взысканием которого налоговый орган обращается в суд, в размере 1500 руб., а затем она была повышена до 3000 руб., поскольку полутора тысяч было не достаточно для покрытия расходов на судебное взыскание. С 2021 г. данный подход распространен на организации и индивидуальных предпринимателей.

${ }^{25}$ См.: Карасева M. В. Деньги - объект имущественных фринансовых правоотношений.

Воронежский государственный университет

Красюков А. В., кандидат юридических наук, доцент кафбедры фбинансового права

E-mail:kav@law.vsu.ru
Voronezh State University

Krasyukov A. V., Candidate of Legal Sciences, Associate Professor of the Financial Law Department

E-mail: kav@law.vsu.ru 